\title{
Do arguments matter? Argumentation and negotiation success at the 1997 Amsterdam Intergovernmental Conference
}

\author{
JANINE REINHARD, JAN BIESENBENDER AND \\ KATHARINA HOLZINGER * \\ Politics and Public Administration, University of Konstanz, Konstanz, Germany
}

\begin{abstract}
It is widely debated in studies of international negotiations why certain negotiators are more successful than others. Institutionalist and rationalist approaches claim that institutions and negotiators' resources largely explain the outcome of negotiations, whereas constructivist approaches stress the importance of shared norms and values. The article asks to what extent the use of normative arguments explains negotiation success in EU treaty negotiations. We apply our approach to the negotiations leading to the Treaty of Amsterdam. We first define normative arguments as justifications for positions that refer to common norms and develop a concept of common values for EU constitutional negotiations. Second, we assess to what degree governments justify their positions by normative arguments using an automated analysis of position papers. Finally, we ask if such justifications increase success in negotiations. The results of our statistical models show that arguing affects negotiation success significantly and positively.
\end{abstract}

Keywords: arguing; norms; EU treaty negotiations; Treaty of Amsterdam; dictionary approach

\section{Introduction}

The EU treaties can be regarded as the constitution of the European Union. As such, they contain the basic rules of the EU's political system and determine the distribution of power. Given their importance for future integration, amendments to the treaties are highly contested among governments, who have to agree unanimously at intergovernmental conferences (IGCs). Therefore, every government is theoretically equipped with the same amount of institutional power. However, it seems widely acknowledged that nevertheless some governments are more successful than others.

Which factors determine success in such international negotiations? Scholars have hypothesized and tested different explanatory factors, such as a member state's size, its economic might, or national ratification constraints (Moravcsik, 1998; Hug and König, 2002; Bailer, 2006; Slapin, 2008; Finke, 2010). This paper

\footnotetext{
* E-mail: katharina.holzinger@uni-konstanz.de
} 
sheds light on an alternative explanation, namely the use of arguments. We ask whether arguments put forward to justify a position significantly influence negotiation success. We focus on normative arguments, which are justifications for particular positions that refer to norms and goals shared throughout the EU. We claim that negotiators who use such normative arguments to back up a bargaining stance are able to impact the negotiation outcome to a larger extent than those who do not. That is, because bargaining positions justified with reference to common norms and the collective interest (understood here as the interest of the EU as a political collective) can hardly be attacked by opponents - unlike positions that obviously serve only the interest of the claimant.

Our argument is based on Schimmelfennig's theory of 'rhetorical action', in which he stresses the importance of arguments for explaining the results of the EU Eastern enlargement negotiations $(2001,2003)$. Further, our research interest in the role of arguments in EU negotiations is in line with recent developments in theories on international negotiations. Whether from a constructivist (Risse, 2000; Dryzek, 2006; Deitelhoff, 2009) or a rationalist understanding (Elster, 1998; Holzinger, 2001, 2004a, 2004b; Schimmelfennig, 2001, 2003) all these authors highlight the importance of arguments to explain the results of particular decision-making processes. However, this theoretical argument has rarely been tested rigorously.

Our approach is innovative on two counts: on the theoretical level, we contribute to the explanation of negotiation success. Our focus on the use of normative arguments tackles an as yet underestimated factor. On the methodological level, we suggest to measure the use of arguments by means of an automated text analysis of government position papers. The data generated is used in a statistical model assessing the impact of arguments while controlling for alternative explanations - member states' size and economic power, their dependency on cooperation, and national ratification constraints. We apply our approach to the 1997 IGC, which led to the Treaty of Amsterdam. The Treaty of Amsterdam was an important step in preparing European institutions for enlargement. In what follows, we first introduce the theoretical background and our hypotheses. We then present the research design and the operationalization of the variables. This is followed by the empirical analysis. The conclusion summarizes the results and highlights issues to be further developed.

\section{Theory and hypotheses}

In this section, we first define our understanding of negotiation success. Second, we present existing work on arguments and its effects in negotiations, our definition of normative arguments, and a theoretical concept that forms the basis for our main hypotheses and their operationalization. Finally, we outline classical rationalist approaches to bargaining power in the $\mathrm{EU}$, which we use as control variables. 


\section{Negotiation success}

We assume that a government's capacities determine its ability to move a negotiation outcome towards its own preferences (Bailer, 2006; Hosli, 2008). Negotiation success then is the degree to which a government was able to use its capacities to shift the bargaining outcome towards its ideal point despite competing preferences of other negotiators. We assume that governments act strategically to realize their most preferred outcome in order to maximize utility. This drives our selection of possible explanatory factors for negotiation success in EU treaty negotiations, which are presented in the following.

\section{Arguments in negotiations}

Our study is embedded in the debate on the role of communication and arguments in decision making. The interest in the role of arguments can be traced back to Habermas (1984). He takes up a normative position according to which the use of arguments occurs in an 'ideal speech situation'; this supposedly leads to a 'reasoned consensus' on collectively best outcomes through deliberation. In this line, Elster $(1995,1998)$ claims that negotiators justify their political goals and exchange arguments based on common values and norms or benefits to the collective interest to reach optimal outcomes.

Such thoughts were taken up in the 'arguing vs. bargaining' debate in international relations (Risse, 2000; Schimmelfennig, 2001; Holzinger, 2001, 2004a, 2004b; Müller, 2004; Niemann, 2004; Dryzek, 2006; Deitelhoff, 2009; Dür and Mateo, 2010; Naurin, 2010). These studies brought attention to the use of arguments in international negotiations, the central claim being that the dominant 'hard bargaining image' based on power, threats, or promises - but not on arguments - as promoted by classical rationalist theory (Morgenthau, 1952; Schneider and Cederman, 1994), cannot be upheld.

While there was agreement that arguments may in fact matter, a conflict arose in terms of whether arguments are used sincerely or strategically (for a summary, see Naurin, 2010). In line with Elster (1995), Holzinger (2001), and Schimmelfennig $(2001,2003)$ were the first to point to the possibly strategic use of arguments, which they labelled 'strategic arguing' (Holzinger, 2004b) or 'rhetorical action' (Schimmelfennig, 2001, 2003). According to Schimmelfennig, 'actors who can justify their interests on the grounds of the community's standard of legitimacy are therefore able to shame their opponents into norm-conforming behaviour and to modify the collective outcome that would have resulted from constellations of interests and power alone' (2001: 48). The successful use of normative arguments depends on the credibility and the quality of normative arguments (Schimmelfennig, 2003: 220). This argument was adapted to study further negotiations, such as the empowerment of the European Parliament (Rittberger, 2005), the constitutionalization of human and minority rights (Schimmelfennig et al., 2006), or WTO negotiations (Niemann, 2004; Morin and 
Gold, 2010). Findings from those qualitative works indicate that arguments are in fact used and that their use influences bargaining outcomes.

This article takes a further step in this direction. Our theoretical argument is based on the conception of rhetorical action: treaty negotiations take place in a 'community environment' in which negotiators share and adhere to certain a priori agreed normative standards. Negotiating in such an environment requires not merely demonstrating power resources and hard bargaining tactics, but legitimizing positions by making reference to common standards. ${ }^{1}$ From the theory of strategic arguing, we derive our central hypothesis on the power of arguments:

The more legitimate normative arguments a government puts forward, the more successfully this government negotiates.

\section{What are normative arguments?}

From the theory of strategic arguing, we learn that not every form of reasongiving and justifying one's position can be effectively used as an argumentative strategy. Schimmelfennig argues that actors in EU treaty negotiations should refer to the 'community standard of legitimacy' (2003: 209). According to him, this legitimacy standard defines appropriate behaviour in a community and is based on the collective identity, the common interest, and shared values and norms (2001: 63). Elster $(1995,1998)$ acknowledges that actors in negotiations justify their political goals and exchange 'impartial' arguments based on common values and norms that deviate from pure self-interest (Elster, 1995: 245). This understanding of arguments narrows the attention from any kind of 'reason-giving' (referring to facts or self-interest) to specific types of arguments, namely those that are related to a community standard of common norms. We will henceforth denote these kinds of arguments as normative arguments.

Now, what are such legitimacy standards - common norms and goals - that EU negotiators can refer to when stating a normative argument? For norms or goals to be valid legitimacy standards in the EU, they should fulfil one basic formal criterion: at some point all negotiators should have agreed upon them in principle and they should still be in agreement at the time of the negotiation. In substantial terms, we rely on Scharpf's (1999: 6-28; cf. 2009) prominent terminology of input- and output-oriented legitimacy as a starting point to identify shared norms. Standards of input legitimacy refer to the democratic quality of decision-making processes, to norms of transparency and democratic accountability, and to the degree of participation and fair representation of those governed. Standards of output legitimacy refer to the political system's problem-solving capacity to and the quality of the policy results.

\footnotetext{
${ }^{1}$ To be sure, this is also consistent with a Habermasian approach of communicative action. We use Schimmelfennig as a background merely because he explicitly refers to the community standards of the EU as legitimacy standards.
} 
In order to find out whether these standards were actually principles agreed upon in the EU, we analysed documents that codified basic principles, common goals, and standards of the community before the Amsterdam negotiation took place: the preamble of the Treaty of the European Union (TEU), the basic principles laid down in Art. 6 TEU, and the Council mandate to the Amsterdam IGC (Presidency Conclusion), which summarizes the goals for the IGC (a similar approach was used by Schimmelfennig, 2003: 265-270 and Hurrelmann et al., 2009: 499).

We find that in fact all theoretical aspects of legitimacy can be identified in these documents. All dimensions of input legitimacy are present, such as references to respect for democratic values and democratic legitimacy (Democratic Decision Making) or appeals to the fair representation of all member states (Fair Representation and Participation). Concerning output legitimacy, we identified many references to the norms of Efficient Decision Making and Problem-Solving Capacity. For the rather abstract concept Quality of Policy Results, we identified two major categories of goals and norms: (1) the Protection of the Process of European Integration and of European Values and (2) the Protection of National Diversity. These norms may compete with one another; however, they are commonly agreed standards. Such standards can be reference points for normative arguments.

For our empirical analysis, we subsume these standards under four broader categories: Democratic Legitimacy (Democratic Decision Making, Transparent Decision-Making Processes, Democratic Accountability, Fair Representation, and Participation), Efficiency (Efficient Decision Making and Problem-Solving Capacity), European Integration (Protection of the Process of European Integration and European Values), and National Diversity (Protect Member States' Diversity). The thus established categorization of normative arguments helps identify arguments in the government position papers. We use the sum of all four categories of arguments as an indicator for the use of normative arguments. These norms may differ in their 'normative weight' - democratic legitimacy or European integration may rank higher than procedural efficiency. As a precise ranking is difficult to justify, however, we treat them as equals.

Two examples from the documents serve to show how the normative arguments appear in the statements of governments. In one position paper (CONF 3846/96), the Italian Government argues that 'Representativeness and democracy require a guarantee that in the Union of 15 , as in a Union of 26 , Council decisions adopted by a qualified majority represent at least $60 \%$ of the population of the Union'. Italy backs up its claim with reference to 'representativeness' and 'democracy'. In another position paper (CONF 3844/96), the Benelux governments state: 'The Council's effectiveness and working methods are in need of improvement. The three governments accordingly argue for the use of qualified-majority voting to be expanded'. The reason given for an extension of qualified-majority voting is the effectiveness of the Council.

These examples demonstrate that justifications of positions do not necessarily come in the form of a classical argument such as 'I want $\mathrm{x}$, because of $\mathrm{y}$ '. Rather, 
arguments appear as an appeal to normative standards; these appeals can take various forms. The important feature is the appeal to certain standards, not the syntactic structure. Therefore, we employ - in line with Schimmelfennig (2003: 200 ) - a broad understanding of 'argument' in terms of the formal structure.

\section{'Classical' explanations for negotiation success}

Purely institutionalist approaches stress the importance of voting rules (Tsebelis, 2002). Given the unanimity requirement at EU IGCs, we should assume that every government is equally powerful because it has the same share of the voting power. ${ }^{2}$ Thus, any government of (however small) a member state that feels that it does not gain enough from a negotiation outcome may threaten to veto a reform enterprise and thereby move the outcome closer to its own ideal point. Consequently, we would assume a uniform distribution of gains as the result of IGC negotiations. However, empirical studies reveal that negotiation success in EU negotiations varies (Bailer, 2006; Slapin, 2006; Arregui and Thomson, 2009).

All those studies, like our analysis, understand EU treaty negotiations as an intergovernmental negotiation process. There is an ongoing debate on whether supranational actors (e.g. Christiansen et al., 2002) or incremental processes between the 'grand bargains' (e.g. Héritier, 2007) should be included to better understand the negotiations. Our focus, however, is solely on the concrete negotiation at the IGC, as we do not strive to explain European integration as such.

Which factors could account for the variation in negotiation success? Whereas our analysis focuses on the variable 'normative arguments', we control for alternative, albeit 'classical' explanations: economic capacity, dependency on cooperation, and ratification constraints.

Economic capacity. The size of a member state in terms of its economic capacity is a measure commonly employed to explain bargaining results in the International Relations and EU literature (see e.g. Slapin, 2008; Dür and Mateo, 2010: 565). Intergovernmentalists such as Moravcsik (1998) or Magnette (2004: 391) argue that big member states are decisive in shaping the results of IGCs and that the size of the market area can be translated into political power. In negotiations, such economic and political power determines whether a government can promise material or political side payments to other member states. In line with this, Moravcsik (1998) claims that preferences of the three largest member states largely explain bargaining outcomes in five major steps in EU integration. Those approaches hypothesize that economically strong member states are more successful in negotiations than those with lower economical weight:

The larger a member state's economic capacity, the more successful its government in negotiations.

\footnotetext{
2 This is demonstrated by voting power indices (see, for example, Hosli, 2002).
} 
Dependency on cooperation. From models of interstate bargaining, we learn that credible threats of either leaving an organization or letting negotiations break down may provide leverage to a negotiator. In the case of EU negotiations, a member state's cost of leaving the organization may either be low because there are alternatives to a negotiated agreement (Lax and Sebenius, 1985). Or, the status quo is acceptable because generally a member state's well-being depends only to a limited extent on a deepening of cooperation (Schneider and Cederman, 1994; Slapin, 2009; see Moravcsik, 1998: 60ff. for a non-formal treatment). In turn, high dependency on cooperation, which implies that no better outside options are available or that the status quo is not acceptable, does not allow for credible veto threats. Therefore, a member state that depends highly on EU cooperation may hardly ever demand concessions from other negotiators but rather be pushed around by others. High dependency on cooperation should lead to less bargaining power:

The lower the dependency on reaching an agreement, the more successful this government in negotiations.

Ratification constraints. Whatever the Heads of State and Government agreed on at an IGC needs to be approved back home. Theoretically, we would assume that the higher the national ratification hurdles, the larger the bargaining power. This follows the simple logic that by threatening with national ratification failure, a government will be able to get concessions from others at the bargaining table (Schelling, 1960; Putnam, 1988; Milner, 1997). This leads to the following conjecture:

The higher the national ratification constraints, the more successful this government in negotiations.

\section{Research design, data, and operationalization}

In the following, we outline why we chose the Amsterdam Treaty as a model case. We describe the operationalization of the variables and the data we use, starting with the dependent variable 'negotiation success', followed by the independents: 'normative arguments' and 'economic capacity', 'dependency on cooperation', and 'ratification constraints' as control variables.

\section{Case selection: the Amsterdam treaty}

We chose the Amsterdam Treaty as an exemplary case because it was one of the major steps in EU history. According to the mandate (Turin Council Presidency Conclusion, 1996), the Amsterdam IGC was supposed to prepare the EU for enlargement, the incorporation of fundamental human rights as well as the modification of some of the policy areas introduced with the Maastricht Treaty, namely Justice and Home Affairs (JHA) and the Common Foreign and Security Policy (CFSP). The driving force for these reforms was the perceived inefficiency in dealing with foreign policy problems (such as the Bosnia War), a perceived legitimacy deficit after the 


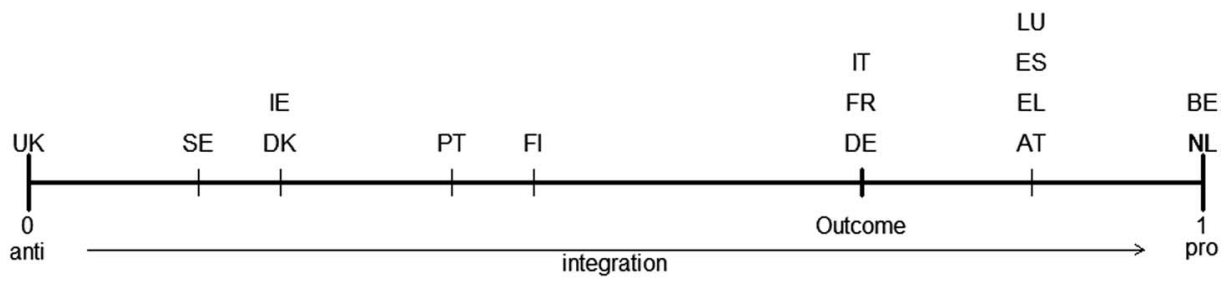

Figure 1 Issue 10, Common Foreign and Security Policy, decision-making procedures (cf. Thurner et al. 2002).

difficult ratification of the Maastricht Treaty, and the upcoming Eastern enlargement to more than 20 member states (Monar and Wessels, 2001), a huge challenge for further European integration. We could thus expect that references to the above described normative categories were made during the negotiations.

In fact, in the course of the Amsterdam IGC a huge amount of position papers were published that we will use to measure the governments' argumentative behaviour. Further, a well-established data set on the governments' negotiation goals is available: the Thurner et al. (2002) data contains the governments' bargaining positions towards all issues at stake as well as the status quo and the negotiation outcome.

\section{The dependent variable: negotiation success}

Data. For the dependent variable 'negotiation success' we employ data collected by Thurner et al. (2002) on government positions. They identify a total of 46 issues at stake at the Amsterdam IGC (2002: 25-29; see Annex 4). For each of the issues, each government's ideal point and the bargaining outcome were collected. The bargaining outcome was identified in documents, the ideal points of each government were asked for in expert interviews. For issue 2, no ideal points could be identified by Thurner et al. (2002). The issue was therefore dropped from the analysis, which leaves us with 45 issues in total. Then, for each issue, the governments' ideal points and the outcome were arrayed in issue spaces, assuming that there is a latent pro - anti-EU integration dimension, ranging from $[0,1]$.

Figure 1 exemplifies this for issue no. 10, which is the decision-making procedure to be applied in the area of CFSP. We see the ideal points of each of the 15 governments, with the United Kingdom being the most integration sceptical government. Substantially, the UK government wanted decisions in CFSP to be taken by qualified majority voting only after a vote had been taken by unanimity. On the other extreme, the Dutch and Belgium government opted to apply qualified majority voting as the basic rule. All other governments' ideal points are somewhere in between. The bargaining outcome, which coincides with the positions of the Italian, French, and German governments, was the application of qualified majority voting for the implementation of policies after a framework decision had been taken by unanimity (see Thurner et al., 2002: 33ff. for further details). 


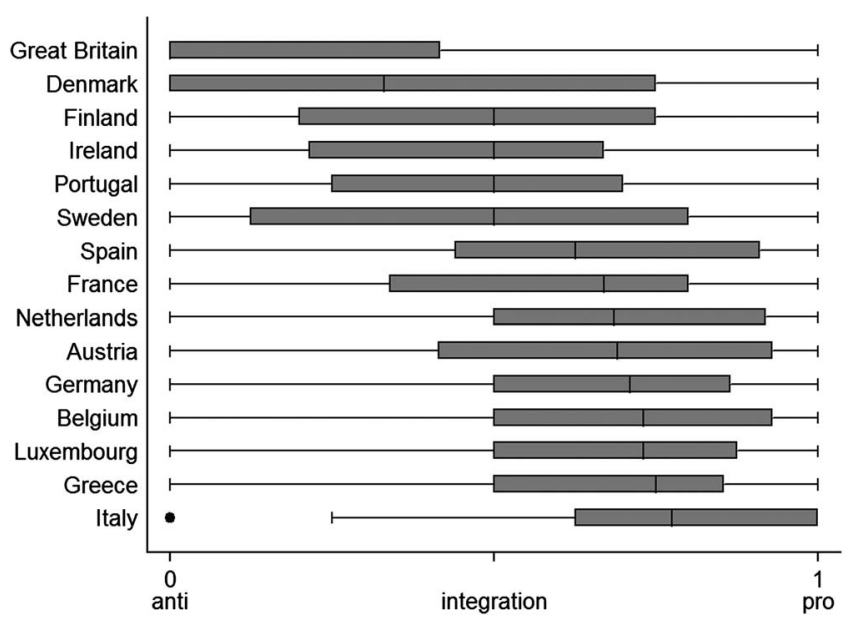

Figure 2 Government's positions on all issues tables.

To give an impression of the positional data, we summarized all the governments' ideal points towards all issues in Figure 2. This boxplot confirms the general intuition: the United Kingdom has the most integration sceptical government indicated by the leftmost median over all issues. Italy is at the other end of the spectrum. Yet, the whiskers, that is, the thin lines coming from the boxes in Figure 2 that indicate the variance of the positions, of almost all governments spread over the whole dimension. This indicates that even rather integration sceptical governments have pro-integration ideal points on one or the other issue, and vice versa.

Given that there are 15 member states and 45 issues, the data set should have 675 observations. However, for 160 of the observations $(23.7 \%)$ there are missing values for government positions and consequently the data set holds 515 observations on the issue-specific negotiation success of every member state (on the problem of missing values, see König et al., 2005: 273; Slapin, 2008: 142).

A measure of negotiation success. To determine negotiation success, we follow the literature (e.g. Bailer, 2006: 199f; Hosli, 2008: 216). We first calculate the absolute distance from the final outcome on an issue $i$ to a government $j$ 's ideal point $i p_{j i}$. We then subtract that value from the maximal attainable value of 1 so that a higher score indicates more negotiation success. This leads to an issue-specific success score on a scale ranging from [0,1] for each government. The more a government was able to reduce the distance from its ideal point to the bargaining outcome, the more successful it was in shaping the outcome.

The thus determined success is weighted with the salience. Salience, measured as the relative importance a government attaches to an issue, is included to take into account that not all issues are equally important to all governments and that only including the importance of an issue allows an estimate of real success 
(Linhart, 2006: 22f.). The inclusion of salience thus serves to draw a more realistic picture of the negotiation process. In real-life negotiations, a voter, legislator, or government may be better-off 'if he accepts a decision contrary to his desire in an area where his preferences are weak in exchange for a decision in his favour in an area where his feelings are stronger' (Buchanan and Tullock, 1962: 162). The Thurner et al. (2002) data contains such a measure. To sum up, a government's success in the Amsterdam Treaty negotiations is calculated as follows:

$$
\begin{gathered}
\text { negotiation success }_{j i}=\left(1-\mid i_{j i}-\text { outcome }_{i} \mid\right) * s_{j i} \text { with } \\
0 \leq s_{j i} \leq 1 \text { and } \Sigma_{i=1}^{m} s_{j i}=1
\end{gathered}
$$

One caveat applies as in such a simple spatial model one can hardly differentiate between power and luck (Barry, 1980) - that is, we cannot truly say whether an outcome has really been influenced by a negotiator or whether this particular government was simply not decisive in shaping the outcome and its ideal point coincides with the outcome by chance. However, given that there are 45 issues it is highly unlikely that any negotiator will be lucky throughout (Bailer, 2006: 194). Furthermore, our measurement might overestimate the negotiation success of more centrally oriented governments, while those at the extremes would be underestimated. To control for this possible bias we create a measure of extremity and relate it to negotiation success. Ideally, both measures do not correlate. The scatter plot (see Annex 1) clearly shows that there is no systematic relation between extremity and negotiation success. Therefore, we can be sufficiently confident that extremity will not bias the analysis.

The summary statistics in Table 1 show the average negotiation success at the Amsterdam IGC for each government. We see that Portugal, Austria, and Luxemburg are on average rather successful negotiators, while Great Britain and France were least successful in shaping the outcome of the Amsterdam negotiations. While variance in negotiation success is not too large, member states are obviously not on completely equal footings. In what follows, we elaborate on the operationalization of factors that may explain this variance.

\section{The independent variable: normative arguments}

Data source: position papers. The central challenge in analysing EU IGCs is posed by the fact that they take place behind closed doors and are oftentimes highly confidential. Minutes or oral protocols of the meetings generally do not exist or are not published (Moravcsik, 1998: 10). Therefore, position papers from individual governments are used to build the independent variable. Altogether, we identified 154 government position papers, which we collected from the Council of Ministers Archives website. ${ }^{3}$ In most cases these documents comprise concrete

\footnotetext{
3 Amsterdam IGC 1996: http://www.consilium.europa.eu/showPage.aspx?id=1298\&lang=EN (updated 10 June 2011). The documents used are provided in our digital document database: http://www.polver.unikonstanz.de/holzinger/dokumentendatenbank/.
} 
Table 1. Dependent and independent variables - descriptive statistics

\begin{tabular}{|c|c|c|c|c|c|c|}
\hline & $\begin{array}{c}\text { Mean } \\
\text { negotiation } \\
\text { success }\end{array}$ & Normative & arguments & GDP & $\begin{array}{l}\text { EU trade } \\
\text { share }\end{array}$ & $\begin{array}{l}\text { National } \\
\text { ratification } \\
\text { constraints }\end{array}$ \\
\hline Austria & $0.125(0.11)$ & $0.174(0.85)$ & 2 & 188 & 62.9 & 19.2 \\
\hline Belgium & $0.122(0.07)$ & $2.239(3.98)$ & 17 & 224 & 76.4 & 11.5 \\
\hline Denmark & $0.116(0.06)$ & $1.109(4.02)$ & 5 & 155 & 66.9 & 26.4 \\
\hline Finland & $0.123(0.14)$ & $0.348(1.59)$ & 3 & 116 & 57.7 & 17.7 \\
\hline France & $0.098(0.09)$ & $0.717(2.53)$ & 5 & 1280 & 62.5 & 16.8 \\
\hline Germany & $0.116(0.09)$ & $0.174(1.18)$ & 1 & 1840 & 57.5 & 14.0 \\
\hline Greece & $0.110(0.10)$ & $3.826(5.25)$ & 27 & 138 & 53.9 & 8.5 \\
\hline Ireland & $0.116(0.06)$ & $0.348(1.85)$ & 2 & 88 & 66.0 & 9.9 \\
\hline Italy & $0.110(0.08)$ & $1.587(2.89)$ & 19 & 1060 & 58.2 & 19.7 \\
\hline Luxembourg & $0.125(0.17)$ & $1.826(3.78)$ & 15 & 19 & 85.4 & 16.3 \\
\hline Netherlands & $0.119(0.19)$ & $1.826(3.78)$ & 15 & 370 & 79.5 & 15.4 \\
\hline Portugal & $0.126(0.08)$ & $2.891(4.45)$ & 19 & 108 & 83.2 & 9.2 \\
\hline Spain & $0.111(0.15)$ & $0.630(2.09)$ & 5 & 553 & 71.2 & 9.2 \\
\hline Sweden & $0.123(0.18)$ & $0.782(5.31)$ & 1 & 232 & 58.4 & 22.5 \\
\hline Great Britain & $0.086(0.06)$ & $2.478(9.76)$ & 6 & 1390 & 58.6 & 20.2 \\
\hline Mean & $0.115(0.12)$ & $1.397(4.25)$ & 9.5 & 517 & 66.6 & 15.8 \\
\hline Description & $\begin{array}{c}\text { Mean } \\
\text { negotiation } \\
\text { success over } \\
\text { all issues; } \\
\text { scale from } 0 \\
\text { to } 1 \text { (std. } \\
\text { dev.) }\end{array}$ & $\begin{array}{c}\text { Mean } \\
\text { number of } \\
\text { normative } \\
\text { arguments } \\
\text { used by a } \\
\text { member } \\
\text { state (std. } \\
\text { dev.) }\end{array}$ & $\begin{array}{l}\text { Number of } \\
\text { issues for } \\
\text { which a } \\
\text { member } \\
\text { state used } \\
\text { normative } \\
\text { arguments }\end{array}$ & $\begin{array}{l}\text { Gross } \\
\text { domestic } \\
\text { product } \\
1997 \\
\text { (constant, } \\
\text { billion } \\
\text { US\$) }\end{array}$ & $\begin{array}{c}\text { Percentage of } \\
\text { total trade a } \\
\text { country } \\
\text { shares with } \\
\text { the EU in } \\
\text { the year } \\
1997\end{array}$ & $\begin{array}{c}\text { Index } \\
\text { combining } \\
\text { ratification } \\
\text { hurdles in } \\
\text { national } \\
\text { parliament and } \\
\text { mean position } \\
\text { of parliament } \\
(1997)\end{array}$ \\
\hline Source & $\begin{array}{l}\text { Own } \\
\text { calculation, } \\
\text { based on } \\
\text { Thurner } \\
\text { et al. }(2002)\end{array}$ & \multicolumn{2}{|c|}{ Authors' own data } & World bank & Eurostat & $\begin{array}{l}\text { Parliamentary } \\
\text { position from } \\
\text { Döring and } \\
\text { Manow (2010) }\end{array}$ \\
\hline
\end{tabular}

GDP $=$ gross domestic product.

suggestions for treaty amendments, sometimes accompanied by a justification for this particular stance. The submitted documents are collected and distributed by the Council Secretariat to the members of all delegations. This ensures that the position papers are received and read by all negotiators. These documents are voluntary statements of governments: the Presidency asks governments' delegations to state their positions in written form but does not give any guidelines on length, content, or style. This ensures that differences in style and content can be interpreted. 
An advantage of position papers in comparison to oral negotiation protocols lies in the fact that written statements are designed very consciously, which diminishes the risk of a redundant use of arguments. We can assume that negotiators use the same argumentative strategies behind closed doors as in the published position papers. This is plausible as negotiators have to be consistent in their argumentative behaviour to remain credible (Schimmelfennig, 2001: 66; Risse and Kleine, 2010: 713). The fact that negotiators tend to use more normative arguments in publicly available position papers than in real negotiations (cf. Risse and Kleine, 2010) should affect all governments in the same way and hence does not influence relative differences between them.

Measuring the use of arguments: an automated dictionary approach. For the measurement of argumentative behaviour, we developed an automated dictionary-based analysis tool that allows the identification of normative arguments. The dictionary approach is a traditional tool from linguistics (Stone et al., 1966) that assumes that the frequency of specific words is an identifier for the content of the whole text corpus. It has recently been adapted to political science to measure policy positions (Laver and Garry, 2000) and framing strategies (Sullivan and Lowe, 2010). Such automated procedures are not as content-sensitive as a manual argumentation analysis. However, the method has two advantages: most importantly, it is possible to apply the tool to large sets of documents and negotiations once a dictionary has been created. Second, automated analyses can be easily replicated and are not sensitive to the individual interpretations of coders.

The dictionary for this study was built inductively on the basis of a manual analysis of a sample of normative arguments from our documents. In a first step, a sample of eight position papers was selected that represents $7.87 \%$ of the words of all 154 published position papers. These position papers were used to manually identify parts of the texts, in which normative arguments were put forward. To code the relevant portions of the text, we used the categories developed in the theory section. This exercise was performed independently by three trained coders according to a codebook. Differences in coding were consensually decided upon.

Second, we determined the frequency of each word in those text passages identified as holding normative arguments. Words that occur frequently in the coded passages are considered characteristic key words for the use of normative arguments. The manually coded text passages were pre-processed before applying the word frequency analysis: we removed 'stop words' (i.e. words that carry no relevant information, such as 'the' 'of' 'in' 'and'). ${ }^{4}$ Additionally, we removed characteristic words for EU negotiations, such as: Europe, EU, institution, parliament, commission, union, member, and state. These words occur in documents on treaty reform very often, but do not carry substantial information of whether arguments are used. The remaining words constitute the dictionary (which can be found in Annex 2).

${ }^{4}$ The list of excluded stop words is taken from: ftp://ftp.cs.cornell.edu/pub/smart/english.stop 
Third, we assigned all position papers or passages thereof to the 45 policy issues identified by Thurner et al. (2002). Thereby, we linked the data set on government positions with the number of arguments used per issue. This allows us to conduct the statistical analysis at the level of individual issues and to relate the negotiation success of a government on an individual issue to its argumentative behaviour on this issue.

Finally, the dictionary was included in a text analysis programme ${ }^{5}$ to measure the degree to which governments use normative arguments. The dictionary analysis reports the absolute number of dictionary key words identified in each text passage assigned to each issue. This way we gain an indicator of the issue-specific usage of normative arguments for each government.

This dictionary procedure cannot account for the quality and credibility of the argumentative statements. The quality of a normative argument is determined by its appropriateness for a certain position and the 'fit' of the norm adhered to with the specific issue and government's position. This is obviously desirable but impossible within the realm of our automated procedure as it requires manual coding according to a scale.

Further, our automated analysis does not consider justifications for positions based on the self-interest of a government or on facts being put forward by a government. It just identifies arguments with reference to a community standard, in line with our core theoretical focus. By manual analysis of a subset of position papers, we observed that justifications that refer to self-interest or to facts are very rare. Even more, in most cases positions are just stated and not justified at all. This might be a consequence of the character of our documents: IGCs are high politics and the authors of the papers are diplomats who are cautious in their wording.

Validity. Automated text analysis approaches such as the dictionary procedure have the advantage of being reliable, but the validity remains a challenge. The internal validity of the measurement concerns the problem of whether the key words of the dictionary are able to correctly identify manually coded arguments. To test this, we apply the dictionary first to the manually coded position papers and check how many key words of the dictionary are found within the manually coded text passages. If the identified words are contained in the manually coded text passages, the dictionary coding is correct. If the dictionary hits a word outside the manually coded passages, the dictionary coding is incorrect. Furthermore, if a manually coded argument is not recognized by the dictionary, its coding is incorrect. Therefore, we analyse a validation file provided by the text analysis programme (see the example in Annex 3). The validity of the coding is satisfying: altogether the dictionary hits 433 words in the manually coded position papers. Of those, $85 \%$ (368 words) are coded correctly and only $15 \%$ or 65 words lie outside the coded passages. Through all analysed position papers, only $10 \%$ of all arguments (14 out of 140) are not identified. To further test

\footnotetext{
${ }^{5}$ For the automatised word frequency and dictionary analysis we use the commercial software MAXqda.
} 
Table 2. Use of arguments by issues

\begin{tabular}{l}
\begin{tabular}{l}
\hline $\begin{array}{l}\text { Number of governments that put forward } \\
\text { an argument for an issue }\end{array}$ \\
\begin{tabular}{l} 
Number of issues \\
\hline
\end{tabular}
\end{tabular} \\
\hline
\end{tabular}

the validity, we analysed a second sample of position papers that was not used to create the dictionary. The results are similar: $89 \%$ (163 out of 183 ) of the dictionary analysis hits are correct codings, $11 \%$ (20) incorrect; only $12 \%$ of all arguments (14 out of 118 ) are not identified.

Descriptive results. For 142 of the 515 data points contained in the Thurner et al. (2002) data we found normative arguments, while for the remaining 373 bargaining stances, no normative arguments were put forward. This number is surprisingly low, which is interesting in itself. ${ }^{6}$ The relative lack of argumentation might be a consequence of the governments' endeavour to keep position papers brief and succinct. Governments might argue only for bargaining positions on which they put high salience, or they might stay silent when they know that another government will argue in favour of their position. Nevertheless, on 36 of the 45 issues at least one government put forward a normative argument. However, the degree varies considerably over the issues (see Table 2). For example, on three issues, nine governments put forward arguments to justify their positions, whereas on six issues only one government decided to use arguments. There are nine issues for which no government used arguments.

The use of arguments also varies between governments in terms of intensity as well as in terms of the number of issues for which an argument is put forward. Descriptive statistics on argumentative behaviour, measured as the number of arguments and the number of issues for which a government used arguments are provided in Table 1. We see that Greece put forward by far the most arguments, whereas Germany and Sweden only argued in the context of a single issue. Portugal, Italy, and the Benelux countries belong to the group using argumentation to a considerable degree, while Austria, Finland, Ireland, Denmark, the United Kingdom, France, and Spain rarely back up their positions with normative references.

\section{Operationalization of the control variables}

Economic capacity: gross domestic product (GDP). As a measure of the political and economic weight of each member state, we employ their GDP. We use data for 1997, that is, the year in which the final negotiations took place and when the Amsterdam treaty was signed by the Heads of State and Government (see Table 1).

\footnotetext{
${ }^{6}$ Examples in the literature show, however, that the use of argumentative speech acts in political speech can be limited to simple claims, rarely making use of normative arguments (for parliamentary debate: Landwehr and Holzinger, 2010). There might be a difference between the extent of explicit argumentation in face-to-face dialogue on the one side, and official political texts, on the other.
} 
On the one extreme, there are the four largest member states, namely Germany, the United Kingdom, France and Italy, while on the other we find Ireland, Portugal, Finland, and Greece. Luxemburg is an outlier in terms of GDP.

Dependency on cooperation: intra-EU trade share. As a proxy for dependency on cooperation, we use the percentage of the total trade (imports plus exports) a member state shares with all the other EU member states. We assume that a high trade share with other EU members makes a government vulnerable to threats of letting negotiations break down. In turn, having a low trade share allows it to press for concessions. This argument applies especially to issues of economic nature, such as 'external economic relations'. But it equally applies to institutional issues concerned with the efficiency of future policy-making in any regulatory policy field concerned with market creation such as the harmonization of process or product standards. Data for these variables comes from Eurostat and were collected for the year 1997 (see Table 1). According to the numbers, Portugal and Luxemburg depend to the largest degree on EU cooperation, while Greece has the smallest intra-EU trade share.

Another possible operationalization would have been Foreign Direct Investment. However, we believe trade is a better measure for two reasons. First, trade is more directly affected by EU regulation than FDI as the latter can occur without any economic integration. Second, the absolute amount of trade in relation to GDP outweighs the FDI/GDP ratio by large margins. Therefore, it should be a more significant indicator empirically.

Ratification constraints. To measure national ratification constraints, we build an index that allows comparing the degree to which governments are constrained in negotiations. Following König (2000), such a measure should incorporate information about the formal rules for ratification at the national level and the policy positions of the ratifying actors. We employ the ratification threshold of the directly elected parliamentary chambers as the national ratification rules. The mere formal ratification thresholds range from a simple majority in the United Kingdom to an $83 \%$ requirement in Denmark. Yet, the mere height of the hurdle may not be too meaningful, given that parliaments may be more or less critical towards a bargaining outcome reached at the European level. In a next step, we therefore combine the ratification threshold with the respective chambers' stance on a pro - anti EU dimension. Using manifesto data on the positions of the parties represented in a chamber, we calculated the chambers' mean positions. ${ }^{7}$ Finally, the mean position is multiplied with the formal ratification threshold. The higher the resulting number, the higher the possibility for a government to credibly threaten a national veto. Table 1 shows that Greece could least credibly

\footnotetext{
7 This is a weighted mean that takes into account the strength of the respective parties measured as the number of representatives. Both the data on the party political composition of the chambers and the manifesto data comes from the ParlGov database (Döring and Manow, 2010).
} 
Table 3. Results 'Empty Model'

\begin{tabular}{lcc}
\hline \hline & $\begin{array}{c}\text { Model 1a } \\
\text { Member state level }\end{array}$ & $\begin{array}{c}\text { Model 1b } \\
\text { Issue level }\end{array}$ \\
\hline Constant & $0.115(0.005)^{* * * *}$ & $0.108(0.009)^{* * *}$ \\
Between-variance & $0.000(0.006)$ & $0.048(0.008)$ \\
Within-variance & $0.118(0.004)$ & $0.107(0.003)$ \\
\hline N/Cluster & $515 / 15$ & $515 / 45$ \\
\hline \hline$* *$ Significant at $1 \%$. & &
\end{tabular}

threaten with national ratification failure, while the governments of the United Kingdom, Sweden, and Denmark could threaten to a much greater extent.

\section{Determinants of negotiation success in the Amsterdam IGC}

\section{Statistical model and dependent variable}

The data is of a hierarchical nature: the dependent variable 'negotiation success' and the independent variable 'issue-specific use of normative arguments' are measured at the level of individual issues; the control variables 'economic capacity', 'dependency on cooperation', and 'ratification constraints' are constant for each member state and do not vary over issues. Additionally, all governments negotiate on the same 45 issues and we can assume that the negotiation success of a government on one issue is not independent of issue-specific factors, for example, the positions and success of other governments. From this it follows that the data structure does not fulfil a central requirement for ordinary least square analysis: the observations are not independent of each other but cluster for each of the 15 member states, as well as for each of the 45 issues.

In a preliminary step, we therefore estimate an empty model (Table 3, Models 1a and $1 \mathrm{~b})$ to analyse the variation of negotiation success among member states. If there is variation on the level of the clusters, that is, the member states and the negotiated issues, the observations are not independent of each other and we must employ multilevel models. The variance components show that the variance in average negotiation success between governments (between-variance) is almost zero (Model 1a). This indicates that member states' average negotiation success over all issues does not vary a lot - as we have already seen above. However, the negotiation success of the individual member states varies considerably between different issues (within-variance). In some issues member states are successful, whereas in others they are not (Model 1b). To handle this data structure we use multi-level analysis.

What explains this variation in negotiation success? Why are member states successful on some issues and not others? Why are some member states more successful when negotiating an issue and others less? In the following, we test which of 
the hypothesized factors ${ }^{8}$ can account for the variation in governments' negotiation success on the level of individual issues and focus on the use normative arguments.

\section{Analysis and findings}

The analysis of the data is carried out in two successive steps. We first estimate which factors affect success across the negotiations on all 45 individual issues. Second, we estimate separate models for different thematic groups of issues to further differentiate our results. For the first step, comparing the argumentation strategies and bargaining resources of successful negotiators for every single issue, we analyse altogether eight models. We choose multi-level random effects models as these can account for issue-specific error terms. ${ }^{9}$ Model $2 \mathrm{a}$ in Table 4 is a bivariate model that estimates the effect of our main variable normative arguments on negotiation success. In the following models, we add the three control variables successively (Models $2 \mathrm{~b}-2 \mathrm{~d}$ ) before we arrive at the first full model (2e). Next, we estimate a model for which we remove influential outliers. Finally, we test the robustness of our results by considering the level of the individual governments. We compare the negotiation success of governments over all issues and ask whether governments are more successful on issues for which they had put forward arguments. Again, we estimate random effects models that assess the influence of normative arguments and control constant factors for all member states. As before, we include (Model 3a) and exclude outliers (Model 3b).

Our main hypothesis that normative arguments positively affect negotiation success is strongly confirmed by the data. This explanatory factor is significant and positive at the $1 \%$ level in the bivariate analysis $(2 \mathrm{a})$, stays significant at the same level when the control factors are included $(2 b-2 d)$, and remains robust for the full model (2e). On average, those governments are more successful that used arguments. The models at member state level (3a) point in the same direction.

Effect size and significance shrink only for the outlier Models ( $2 \mathrm{f}$ and $3 \mathrm{~b}$ ). An analysis of influential outliers (Empirical Bayes Predictors) identifies the negotiations on issue 7 (Transparency: Opening council's proceedings) and issue 17 (Modes of action within JHA) to be influential outliers. In the negotiations on issue 7, Sweden was very successful and used many normative arguments. Issue 17 represents a negative outlier: Great Britain was the least successful country and, at the same time, was the only country using normative arguments. To rule this bias out we excluded these two issues. The model ( $2 \mathrm{f})$ shows that the effect is weaker but still significant.

\footnotetext{
${ }^{8}$ We tested the independent variables for collinearity. The highest correlation coefficient is between GDP and Intra-EU trade share (Pearson's r: -0.42). This is still small enough to rule out multicollinearity. All other coefficients lie far beyond this number.

9 A Hausman test was conducted to check whether fixed or random effects models are more appropriate. The results suggest we employ random effects models.
} 
At the level of member states, the governments of Sweden and Spain turn out to be influential outliers. For these two countries, the use of normative arguments has an enormous influence on their negotiation success. This is driven by two extreme cases: Sweden's influence arises from the above described negotiations on issue 7. This was the only issue during the whole negotiation for which Sweden used arguments. 'Transparency in the Decision-Making Process' has traditionally been a highly salient issue for Sweden compared with other governments. This case raises the average influence of arguments on Sweden's negotiation success considerably. Spain used normative arguments for seven issues, but the most arguments were used for issue 16 'Objectives and Scopes within Justice and Home Affairs', the issue in which Spain was most successful in the Amsterdam negotiations. We conducted the analysis without issues 7,16 , and 17 . This reduces the influence of normative arguments; however, it is still significant (Model 3b).

The influence of the three control variables economic capacity, dependency on cooperation, and ratification hurdles is not confirmed by our analysis. For all models, none of these factors have a significant effect. We ran an additional model without the variable normative arguments, which corroborated this finding. Given the prominence these factors have in the literature this result is rather surprising. As the theoretical considerations have high plausibility, we may doubt whether the - conventional - operationalizations are appropriate. We measure the existence of a bargaining resource but not whether this resource was really translated into a bargaining strategy. We cannot observe if a country uses its ratification hurdles to threaten with domestic ratification failure or whether a large country really offers side payments. However, these are widespread measurements that were used in many studies.

A more substantial explanation points to an institutional factor: EU treaty negotiations take place under unanimity rule. The institutional veto power of each government may well override the structural power resources of the countries. This is not in line with the claims of Moravcsik (1998) and others, however, more recent studies point in a similar direction (Bailer, 2006; Slapin, 2006, 2008).

Finally, the structure of the data is an indicator that a more differentiated perspective might provide an answer: the control variables are country-level variables and we saw that variance in negotiation success is very low at this level (Table 3, Model 1a) but present at the issue level (Model 1b). As negotiation success is rather equal if averaged over all 45 issues, the differences in bargaining resources may cancel each other out in the aggregate. This does not mean that they do not play out in individual instances. Bailer's analysis shows considerable variance in the influence of bargaining resources for different thematic policy areas (2004: 114).

Therefore, and in a second step of the analysis, we take a closer look at the thematic issues. Do the variables have a different influence on negotiation success, dependent on the thematic issue discussed? In a first exploration, we conduct the regression analysis for every thematic issue group, as distinguished by 
Table 4. Results regression analysis

\begin{tabular}{|c|c|c|c|c|c|c|c|c|}
\hline & Model 2a & Model 2b & Model 2c & Model 2d & Model 2e & Model 2f & Model 3a & Model 3b \\
\hline Variables & Arguments & Arguments + GDP & Arguments + trade & Arguments + ratification & Full model & $\begin{array}{c}\text { Full Model I } \\
\text { (without outliers) }\end{array}$ & $\begin{array}{l}\text { Full Model } \\
\text { (MS-Level) }\end{array}$ & $\begin{array}{l}\text { Full Model II (without } \\
\text { outliers) }\end{array}$ \\
\hline Arguments & $0.0042(0.0011)^{* * * *}$ & $0.0041(0.0011)^{* * * *}$ & $0.0041(0.0011)^{* * * *}$ & $0.0042(0.0011)^{* * * *}$ & $0.0041(0.0011)^{* * * *}$ & $0.0026(0.0011)^{* * *}$ & $0.0040(0.0011)^{* * * *}$ & $0.0021(0.0012)^{*}$ \\
\hline GDP & & $-0.0000(0.0000)$ & & & $-0.0000(0.0000)$ & $-0.0000(0.0000)$ & $-0.0000(0.0000)$ & $-0.0000(0.0000)$ \\
\hline Trade share & & & $0.0003(0.0005)$ & & $0.0002(0.0005)$ & $0.0001(0.0005)$ & $0.0002(0.0006)$ & $0.0001(0.0005)$ \\
\hline Ratification & & & & $-0.0002(0.0009)$ & $0.0001(0.0010)$ & $-0.0001(0.0010)$ & $0.0003(0.0011)$ & $0.0004(0.0010)$ \\
\hline Constant & $0.1011(0.0092)^{* * * *}$ & $0.1058(0.0099)^{* * * *}$ & $0.0788(0.0324)^{* * *}$ & $0.1038(0.0172)^{* * * *}$ & $0.0916(0.0450)^{* * *}$ & $0.0971(0.0430)^{* * *}$ & $0.0963(0.0483)^{* * *}$ & $0.0986(0.0451)^{* * *}$ \\
\hline $\begin{array}{l}N \text { (cluster/ } \\
\text { observations) }\end{array}$ & $45 / 515$ & $45 / 515$ & $45 / 515$ & $45 / 515$ & $45 / 515$ & $43 / 486$ & $15 / 515$ & $15 / 472$ \\
\hline Wald $\chi^{2}$, prob $>\chi^{2}$ & 0.00001 & 0.00004 & 0.0005 & 0.0006 & 0.0036 & 0.1530 & 0.0065 & 0.3396 \\
\hline
\end{tabular}

Notes: GDP = gross domestic product.

$\mathrm{SE}$ in parentheses.

***Significant at $1 \%$, * Significant at $5 \%$, "Significant at $10 \%$.

Source: Authors' own data. 
Table 5. Results regression analysis - influence for thematic issue groups

\begin{tabular}{|c|c|c|c|c|c|c|}
\hline \multirow{2}{*}{ Variables } & \multicolumn{6}{|c|}{ Issue groups } \\
\hline & Model 4a & Model 4b & Model 4c & Model 4d & Model 4e & Model 4f \\
\hline Arguments & $0.002(0.0009) * *$ & $0.006(0.0039)$ & $0.0003(0.0044)$ & $-0.0001(0.0038)$ & $0.0076(0.0040)^{*}$ & $0.0014(0.0027)$ \\
\hline GDP & $-0.00001(0.00001)$ & $-0.0000(0.0000)$ & $0.0000(0.0000)$ & $0.00002(0.0000)$ & $0.00002(0.0000)$ & $-0.00004(0.0000)^{*}$ \\
\hline Trade share & $-0.0005(0.0008)$ & $-0.0042(0.0012) * * *$ & $0.0043(0.0020)^{* * *}$ & $0.0026(0.0012)^{* * *}$ & $0.0006(0.0010)$ & $-0.0010(0.0013)$ \\
\hline Ratification & $-0.0012(0.0015)$ & $-0.0010(0.0021)$ & $-0.0047(0.0040)$ & $0.0015(0.0021)$ & $-0.0010(0.0020)$ & $0.0035(0.0023)$ \\
\hline Constant & $0.1165(0.071)$ & $0.4408(0.097)^{* * *}$ & $-0.0547(0.172)$ & $-0.0825(0.0969)$ & $0.0404(0.0820)$ & $0.1020(0.1061)$ \\
\hline $\begin{array}{l}N \text { (issue/ } \\
\text { observations) }\end{array}$ & $06 / 52$ & $7 / 94$ & $6 / 70$ & $9 / 115$ & $10 / 91$ & $6 / 79$ \\
\hline Wald $\chi^{2}$, prob $>\chi^{2}$ & 0.1919 & 0.0088 & 0.0460 & 0.3091 & 0.1872 & 0.1362 \\
\hline
\end{tabular}

Notes: CFSP $=$ Common Foreign and Security Policy; JHA = Justice and Home Affairs.

$\mathrm{SE}$ in parentheses. Bold values indicating the significance levels.

$* *$ Significant at $1 \%, * *$ Significant at $5 \%, *$ Significant at $10 \%$.

Source: Authors' own data. 
Thurner et al. (2002). ${ }^{10}$ Unfortunately, the number of observations in every thematic issue field is quite small and thus the results should be interpreted with caution.

Indeed, our analysis reveals differences in the influence of bargaining resources for different thematic issue domains (Table 5, Model 4a-4f). We observe an interesting result: no explanatory factor has a robust effect across all issue domains. Normative arguments have a significant positive effect in negotiations on 'Fundamental Legal Questions' and on 'Power Distribution between EU Institutions'. For those issues the effect of the community standards might be stronger than for other issue groups and, hence, reference to common norms has a significant influence on negotiation success. In contrast, in negotiations on 'Collective Decision-making Institutions', a domain that seriously affects the influence of governments in future decision making and the distribution of power between them, the use of normative arguments even seems to negatively influence negotiation success - although this effect is small and not significant.

Economically powerful governments have less negotiation success in negotiations on the communitarization of 'Further Competences', whereas the results are insignificant for the other issues groups. Member states with a high dependency on cooperation are in two issue groups - contrary to the conjectures of conventional theory - significantly more successful ('Justice and Home Affairs' and 'Collective Decision-Making Institutions'), in negotiations on 'Common Foreign and Security Policy' significantly less. This indicates that veto threats as the strategy for the less-dependent negotiations are not promising for negotiations on 'Justice and Home Affairs' and 'Collective Decision-Making Institutions'. At the same time, the positive statistical relationship does not establish a causal link between a high dependency on cooperation and negotiation success. Probably, those countries that depend very much on cooperation use other strategies that positively influence their negotiation success in these important issue areas. Eventually, for governments that can threaten with ratification failure, the third control variable, the influence on negotiation success also remains insignificant in the thematic issue models. In sum, the main shift occurs from normative arguments towards dependency on cooperation as explanatory factors in thematic areas that distribute power among member states - as opposed to issue domains such as the degree of integration in certain policy fields or fundamental normative questions.

\section{Conclusion}

In this paper, we evaluated the power of normative arguments for explaining the negotiation success of the EU governments in the negotiations leading to the Treaty of Amsterdam. Although the role of arguing is widely debated in International Relations, so far no attempts have been made to empirically assess its

\footnotetext{
${ }^{10}$ A description of the exact issues subsumed under a thematic issue group and its policy options can be found in Thurner et al. (2002: 25-29).
} 
effect in EU treaty negotiations. We developed a measurement concept of normative arguments to find out to what degree member state governments justify their political stances in position papers. We tested the influence of normative arguments on the success of governments using a statistical model that included classical bargaining resources as control variables.

At the descriptive level, we first find that arguments are used by the governments to a varying degree. While some governments (e.g. Greece) present many arguments with respect to many bargaining issues, others do not bother to do so (e.g. Germany). Similarly, while for some of the 45 issues there is much argumentation, for others no government presents normative references. It is important to note that arguments are put forward only for a fraction of all possible bargaining positions. Second, negotiation success, measured as the degree to which a government can move a negotiation outcome towards its own ideal point, is rather equally distributed across member states if aggregated over all issues. There is variation in success, however, at the level of individual issues.

Our 'rhetorical-actions'-hypothesis, that the reference to normative arguments increases negotiation success, is clearly confirmed. In a second statistical approach, we tested negotiation success for different thematic issue groups. We find that the effect of arguments varies over the themes, with arguing being particularly successful on issues concerned with fundamental legal questions and the distribution of power between the EU institutions.

Surprisingly, classical bargaining resources are found to be less influential. In the model aggregating all issues, neither economic capacity, dependency on cooperation, nor ratification constraints show any significant results. The differentiation according to thematic issue groups changes the picture: dependency on cooperation affects negotiation success in particular for issues that belong to the intergovernmental sphere.

The study offers three main contributions. First, we enrich the rational choice debate on power and success in EU negotiations by an additional factor, the use of normative arguments. Second, numerous case studies based on the explanatory power of argumentation chose only positive cases and hence could not control for the effect of contextual factors. The added value of this study is to take a broader view and look at a broad sample of negotiated issues, in fact all issues negotiated in the context of one EU treaty. Third, we apply an innovative method, namely the dictionary approach, to the measurement of arguments. This instrument allows measuring the use of argumentative patterns over a large amount of documents. The reliability and internal validity is high, however, the automatized procedure cannot assess the quality of arguments put forward regarding appropriateness, consistency, and credibility. Further empirical analyses can use the proposed dictionary approach and the conceptualization of normative arguments in the context of the EU.

Two caveats are necessary. First, the result that classical bargaining resources do not matter is surprising. It remains open whether this is due to the operationalization 
of the variables or to the unanimity rule - the latter would actually represent a positive indication for the legitimacy of EU decisions, as the aim of the unanimity rule is to give every member state government, may it have a structurally strong or weak position, an equal weight in EU negotiations. Finally, this result might be a consequence of particularities of the Amsterdam negotiations.

This alludes to the second limitation of our study: we applied our instrument only to a single case of EU treaty negotiations, whereby the generalizability is limited. The results might be influenced by the specificities of the Amsterdam process. To evaluate the extent to which we can generalize the findings from the Amsterdam IGC to other EU intergovernmental negotiations, further studies should be conducted. An analysis of other IGCs, such as the negotiations leading to the Treaty of Nice, the Constitutional Treaty and the Lisbon Treaty, is a task for further research. The analysis of further IGCs would also increase the number of observations and the analysis of thematic issue groups could be based on a more robust database. Such research could also reveal why governments use arguments for specific issues and why the use of arguments is especially successful in some issues and not in others.

\section{Supplementary material: Annex}

To view supplementary material for this article, please visit http://dx.doi.org/ 10.1017/S1755773913000064

\section{References}

Arregui, J. and R. Thomson (2009), 'States' bargaining success in the European Union', Journal of European Public Policy 16(5): 655-676.

Bailer, S. (2004), 'Bargaining success in the European Union. The impact of exogenous and endogenous power resources', European Union Politics 5: 99-123.

- (2006), 'The dimensions of power in the European Union', Comparative European Politics 4(4): $355-378$.

Barry, B. (1980), 'Is it better to be powerful or lucky? Part 1', Political Studies 28(2): 183-194.

Buchanan, J.M. and G. Tullock (1962), The Calculus of Consent. Logical Foundations of Constitutional Democracy, Ann Arbor: University of Michigan Press.

Christiansen, T., G. Falkner and K.E. Joergensen (2002), 'Theorizing EU treaty reform: beyond diplomacy and bargaining', Journal of European Public Policy 9(1): 12-32.

Deitelhoff, N. (2009), 'The discursive process of legalization: charting islands of persuasion in the ICC case', International Organization 63(1): 33-65.

Döring, H. and P. Manow (2010), Parliament and government composition database (ParlGov): an infrastructure for empirical information on parties, elections and governments. Retrieved 1 June 2011 from http://parlgov.org/.

Dryzek, J.S. (2006), Deliberative Global Politics, Cambridge: Polity Press.

Dür, A. and G. Mateo (2010), 'Bargaining power and negotiation tactics: the negotiations on the EU's financial perspective, 2007-13', Journal of Common Market Studies 48(3): 557-578.

Elster, J. (1995), 'Strategic uses of arguments', in K. Arrow (ed.), Barriers to Conflict Resolution, New York: Norton, pp. 237-255.

- (1998), 'Deliberation and constitution making', in J. Elster (ed.), Deliberative Democracy. Cambridge: Cambridge University Press, pp. 97-122. 
Finke, D. (2010), European integration and its limits: intergovernmental conflicts and their domestic origins, Essex: European Consortium for Political Research Press.

Habermas, J. (1984), The Theory of Communicative Action. Vol. 1 of Reason and the Rationalization of Society. Boston: Beacon Press.

Héritier, A. (2007), Explaining Institutional Change in Europe, Oxford: Oxford University Press.

Holzinger, K. (2001), 'Kommunikationsmodi und Handlungstypen in den Internationalen Beziehungen. Anmerkungen zu einigen irreführenden Dichotomien', Zeitschrift für Internationale Beziehungen 8: $243-286$.

_ (2004a), 'Bargaining by arguing. An empirical analysis based on Speech Act Theory', Political Communication 21: 195-222.

- (2004b), 'Strategic arguing', Swiss Political Science Review 10: 201-210.

Hosli, M. (2002), 'Preferences and power in the European Union', Homo Oeconomicus 19: 311-326. (2008), 'Negotiating European economic and monetary union', Homo Oeconomicus 25(2): 203-223.

Hug, S. and T. König (2002), 'In view of ratification: governmental preferences and domestic constraints at the Amsterdam intergovernmental conference', International Organization 56(2): 447-476.

Hurrelmann, A., Z. Krell-Laluhove, F. Nullmeier, S. Schneider and A. Wiesener (2009), 'Why the democratic nation-state is still legitimate: a study of media discourses', European Journal of Political Research 48: 483-515.

König, T. and S. Hug (2000), 'Ratifying Maastricht: Parliamentary Votes on International Treaties and Theoretical Solution Concepts', European Union Politics 1(1): 93-124.

König, T., D. Finke and S. Daimer (2005), 'Ignoring the non-ignorables? Missingness and missing positions', European Union Politics 6(3): 269-290.

Landwehr, C. and K. Holzinger (2010), 'Institutional determinants of deliberative interaction', European Political Science Review 2(4): 373-400.

Laver, M. and J. Garry (2000), 'Estimating policy positions from political texts', American Journal of Political Science 44(3): 619-634.

Lax, D.A. and J.K. Sebenius (1985), 'The power of alternatives or the limits to negotiation', Negotiation Journal 1: 163-179.

Linhart, E. (2006), Die Erklärungskraft spiel- und tauschtheoretischer Verhandlungsmodelle in Abhängigkeit vom Institutionalisierungsgrad des Verhandlungssystems, Mannheim: Mannheim University Press.

Magnette, P. (2004), 'Deliberation or bargaining? Coping with constitutional conflicts in the convention on the future of Europe', in Erik. O. Eriksen, John E. Fossum and Augustin J. Menendez (eds), Developing a Constitution for Europe, London: Routledge, pp. 207-225.

Milner, H.V. (1997), Interests, Institutions, and Information: Domestic Politics and International Relations, Princeton: Princeton University Press.

Monar, J. and W. Wessels (2001), European Union After the Treaty of Amsterdam, London: Continuum.

Moravcsik, A. (1998), The Choice for Europe: Social Purpose and the State Power from Messina to Maastricht, Ithaca: Cornell University Press.

Morgenthau, H.J. (1952), 'The national interest of the United States', American Political Science Review 46: 961-988.

Morin, J.-F. and E.R. Gold (2010), 'Consensus-seeking, distrust and rhetorical entrapment: The WTO decision on access to medicines', European Journal of International Relations 16(4): 563-587.

Müller, H. (2004), 'Arguing, bargaining and all that: communicative action, rationalist theory and the logic of appropriateness in international relations', European Journal of International Relations 10(3): 395-435.

Naurin, D. (2010), 'Most common when least important: deliberation in the European Union Council of Ministers', British Journal of Political Science 40(1): 31-50.

Niemann, A. (2004), 'Between communicative action and strategic action: the Article 113 Committee and the negotiations on the WTO Basic Telecommunications Services Agreement', Journal of European Public Policy 11(3): 379-407.

Putnam, R.D. (1988), 'Diplomacy and domestic politics: the logic of two-level games', International Organization 42(3): 427-460. 
Risse, T. (2000), 'Let's argue! Communicative action in international relations', International Organization 54(1): 1-39.

Risse, T. and M. Kleine (2010), 'Deliberation in negotiations', Journal of European Public Policy 17(5): 708-726.

Rittberger, B. (2005), Building Europe's Parliament: Democratic Representation Beyond the Nation State, Oxford: Oxford University Press.

Scharpf, F.W. (1999), Governing in Europe: Effective and Democratic?, Oxford: Oxford University Press.

- (2009), 'Legitimacy in the multilevel European polity', European Political Science Review 1(2): 173-204 doi:10.1017/S1755773909000204.

Schelling, T.C. (1960), The Strategy of Conflict, Cambridge: Harvard University Press.

Schimmelfennig, F. (2001), 'The community trap: liberal norms, rhetorical action, and the Eastern enlargement of the European Union', International Organization 55(1): 47-80.

- (2003), The EU, NATO and the Integration of Europe, Cambridge: Cambridge University Press.

Schimmelfennig, F., B. Rittberger, A. Bürgin and G. Schwellnus (2006), 'Conditions for EU constitutionalization: a qualitative comparative analysis', Journal of European Public Policy 13(8): 1168-1189.

Schneider, G. and L.-E. Cederman (1994), 'The change of tide in political cooperation: a limited information model of European integration', International Organization 48(4): 633-662.

Slapin, J.B. (2006), 'Who is powerful? Examining preferences and testing sources of bargaining strength at European intergovernmental conferences', European Union Politics 7(1): 51-76.

- (2008), 'Bargaining power at Europe's intergovernmental conferences: testing institutional and intergovernmental theories', International Organization 62(1): 131-162.

- (2009), 'Exit, voice, and cooperation: bargaining power in international organizations and federal systems', Journal of Theoretical Politics 21(2): 187-211.

Stone, P., D.C. Dunphy, M.S. Smith and D.M. Ogilvie (1966), The General Inquirer: A Computer Approach to Content Analysis, Cambridge, MA: MIT Press.

Sullivan, J. and W. Lowe (2010), 'Chen Shui-bian: on independence', China Quarterly 203: 619-638.

Thurner, P.W., F.U. Pappi and M. Stoiber (2002), 'EU intergovernmental conferences. A Quantitative Analytical Reconstruction and Data-Handbook of Domestic Preference Formation, Transnational Networks, and Dynamics of Compromise during the Amsterdam Treaty Negotiations'. Mannheim: Mannheimer Zentrum für Europäische Sozialforschung.

Tsebelis, G. (2002), Veto Players. How Political Institutions Work, Princeton: Princeton University Press. 